\title{
'Facts are Tenacious'-Interweaving Power Pedagogy in Social Capital Theory to Galvanise Participatory Development: A Critique
}

\author{
Fikile Vilakazi, PhD \\ Institute for Social Development, University of the Western Cape, South Africa \\ Email: fikile.vilakazi@gmail.com \\ Dr Mulugeta F. Dinbabo \\ Institute for Social Development, University of the Western Cape, South Africa \\ Email:mdinbabo@uwc.ac.za
}

Doi:10.5901/mjss.2014.v5n14p492

\begin{abstract}
The aim of this research was to measure the level of participation amongst African Traditional Health Practitioners at Thembisile Hani local municipality in Mpumalanga and examine whether trust, reciprocity and power affect public participation in the regulation of African Traditional Medicines in South Africa using a social capital theoretical model. The study employed a quantitative methodology by carrying out a survey using a structured questionnaire and data was analysed using a classical linear regression model where $Y=a+b K+c X+d L+\mu$, where $a$ is the intercept of the model, $b, c$, and $d$ represent regression coefficients, and $\mu$ is the random error term. However, the focus of the study was on the public participation regression coefficient (c), whose value gives the effect of public participation. The results show that $57 \%$ of respondents believed that the constitution gives them the power to influence public decisions; however that citizen power is not being activated whilst $36 \%$ of respondents did not believe that they had similar power. One key reason cited by both respondents was that government will always do what they want to do regardless of what citizens think or say. The correlation between power and public participation $(p>=0.004)$ in this study was statistically significant. The conclusion is that the creation of social capital requires an inclusion of power pedagogy in social capital theory through a proposed CRCT model which creates centres for power interrogation within networks.
\end{abstract}

Keywords: power, trust, reciprocity, participation, social capital theory.

\section{Introduction}

Since 1996, South Africa has enacted various pieces of legislation (Nyalunga, 2006: 2) to foster and encourage public participation by citizens on matters affecting people's daily lives. The Constitution of South Africa provides, in section 72(1) (a), that the 'National Council of Provinces must facilitate public involvement in the legislative and other processes of the council and committees' and in section 118 (1) (a) that provincial legislatures must do the same (South Africa Presidency, 1997:25). Despite such provisions, public participation remains a constitutional right that has not been realised and experienced by the majority of South Africans. A huge disjuncture exists between legislative and policy guarantees and the real experiences of people within communities, particularly in isolated, poor settlements.

Recent studies show that 'lack of awareness' and 'the state's reluctance to engage civil society' thwarted public participation (Tadesse et al 2006:15). According to Buccus et al. (2007:18) citizens view public participation as an act of being 'used to legitimate decisions that have already been taken at higher [government] level'. Furthermore, the Public Service Commission [PSC] (2008:18) found that ' $75 \%$ of government departments; both national and provincial did not have guidelines or policies on public participation'. In addition, Scott (2009:2) found that 'no public participation framework exists in the country to guide the legislative sector in its public participation drive.

We conducted a study to assess levels of participation in the regulation of traditional medicines in South Africa focussing on African Traditional Health Practitioners at the Thembisile Hani Local Municipality located in Mpumalanga province situated in the East of South Africa. The study analysed correlation between participation, trust in government, citizen's willingness to participate in public processes (reciprocity) and the power of citizens in democratic processes. 


\section{Theoretical Framework}

The theory of participation was made popular by the work of Arnstein in the 1960s through the concept of the 'ladder of participation' (Arnstein, 1969: 261-224). Essentially, Arnstein's ladder of participation presents three different types of participation, including 'passive participation, tokenism and citizens control' (Cornwall, 2008: 270), with the latter being viewed as an ideal state of active participation in which citizens have full control. Burns, Hambleton and Hoggart (1994:69) introduced the concept of 'citizen power' in the participation ladder instead of 'citizen control'.

Penderis (2012: 5) argues that it is becoming increasingly clear that engaging, consulting and involving local people rarely results in anticipated goals of em(power)ment and transformation', confirming the need to focus on the type of participation that fosters citizen power and control. Some scholars argue that it is time 'to jump off the Arnstein's ladder due to its insufficient ability for making sense of participation at a conceptual and practical level' (Collins \& Ison, 2006:2).

Contrary to Collins \& Ison, our argument is that 'Citizen Power' in Arnstein's ladder of participation remains one of the valuable contributions in the study of participation in social sciences. However, a further theoretical development is required to interrogate the distribution and sharing of power in participation in ways that activates 'citizen power', justice and good governance in democratic societies. Chambers (1994a: 2) proposes a 'paradigm shift from things to people ... and .... a transfer of power from tops to bottoms to promote people centred participation'. This resulted in the formulation of 'participatory rural appraisal which emphasises the reversal of learning from top to bottom' (Chambers, 1994b: 1204).

Kapoor (2002:102), on the other hand, thinks that Chambers puts too much emphasis on practice and argues that 'the danger of fetishising practice is that it tends to posit a 'pure' practice that can proceed without bias or theoretical abstractions, independent of, and unfettered by, political concerns about justice and legitimacy' in participatory development.

Putnam (2000:19) on the other hand presents social capital as an alternative theoretical course to foster civic participation, which is defined as "connections among individuals-social networks and the norms of reciprocity and trustworthiness that arise from them'. Theorising social capital is not a new development in academic literature. The intellectual thinking first emerged in the work of Hanifan (1916:130) when reference was made to 'good will, fellowship, sympathy and social intercourse as tangible forces that count for most in daily life'.

It may even be traced back as early as the 1800 s from classical Marxist writings, including 'Marx's idea of class consciousness (Ollman, 1968:1-572-580), Lenin's concept of the vanguard (Cliff, 1973:34-38) and Gramsci's notion of ideological hegemony' (Gundogan, 2008:45-60). Various scholars have written widely about the idea of social capital, including Loury, 1977, Coleman, 1988, and Becker, 1996, amongst others. Whilst the concept may be worth retrospection, the scope of this paper is limited to theoretical insights provided by Putnam (2000:19). The idea of social capital is embedded in actions of reciprocal exchanges amongst collectives of people who are connected by virtue of trusting one another. A group in Putnam's definition can be two individuals, a family, an association, a political party and/or government. Portes (2007:1), however, is persuaded that 'the greatest theoretical promise of social capital lies at an individual level'. Unlike Portes, our argument is that social capital is by conceptualisation a group theory, and, it can be used to interrogate group dynamics.

Nonetheless, the challenge with Putnam's concept of social capital is that it places too much emphasis on trust and reciprocity without stressing other variables that are possible enablers or inhibitors of trust and reciprocity in society, such as power, inequality, class, gender and sexuality inter alia. There is an assumption that societal collectives are naturally ordered and can function cohesively by virtue of inherent trust and reciprocity. This view is similar to that of functionalist theory in which parts of a system are viewed as capable of functioning by virtue of being integrated with one another (Block, 1975:171). Franklin (2007:12), likewise, asserts that the functionalist nature of Putnam's social capital 'undermines (the power) of conflict and contradictions that persist' in social collectives.

It is important to understand that 'trust' is essential for building and sustaining social capital in society, but because trust, once constructed, lives in people's hearts, it is therefore personal and because it has influence in social relations, it is also political (Kleinman, 2007:2). Bilgic (2013:10) is convinced that trust is a force that makes collective life possible; without it, 'egocentrism marks relations between individuals in a collective'. Democratic theory suggests that democracies need trustful citizens.

This is the case because, symbolically, governments and parliaments have to enjoy legitimacy between one election and the next but also because, pragmatically, mistrustful citizens tend to pay less tax (Della Porta, 2012:34). Given this scenario, the value of trust cannot be underestimated as a necessary value for building social capital in society. It can build or destroy democracies. Mollering (2001:404) defines trust as 'a state of favourable expectation regarding other people's actions and intentions'.

Equally, the norm of reciprocity is fundamentally important for the effective functioning of social networks in society. 
Gouldner (1959:70), describes reciprocity as a 'social rule that maintains, among other things that people should return favours and other acts of kindness'. The principle of the 'Golden Rule-love thy neighbour as God loves you and do unto others as I have done to you' found in most orthodox religions '(Judaism, Greek mythology and philosophy, Zoroastrianism, Christianity, Islam, Buddhism, Hinduism, and Confucianism)' for, instance, tends to be interpreted as an act of unconditional reciprocity motivated by a reward from a cosmic force (Neusner \& Chilton, 2008:732). The challenge is that 'modern social relationships seem too complex, too strongly institutionally or systemically mediated to be capable of being traced back to arrangements of reciprocity' (Adloff \& Mau, 2013:95). It is acknowledged however that 'from the kinship structures of primitive peoples,... to the vast sharing of software and information on the modern internet, systems of generalized exchange [reciprocity] have always been a ubiquitous part of social life'.

Our postulation is that in contemporary politics 'trust' and 'reciprocity' do not have the same character that they possessed in primitive times which was kind, giving and believed in the natural goodness of fellow human beings for the betterment of all. Social exchange theory reminds us that reciprocity as 'whether (direct) - where two actors exchange resources with each other, or, (indirect) - where the recipient of the benefit does not return the benefit back to the giver but to another actor' (Molm, Collett, \& Schaefer 2007:207), is a 'cost-benefit' arrangement based on competitive social systems that lead to differentiation of power and privilege within social collectives (Yakubovich, 2002, 4).

In addition, 'trust is a dynamic and continually changing property of human relationships' (Stahl, 2009:12). It is not static. Anheier and Kendall (2000:9) caution that trust is 'fragile; once violated, [it] is difficult to re-establish'. It is for this reason that feminist theory introduces the idea of 'emotional liberation, [a process where] trusting individuals are capable of detaching themselves from old loyalties' and forge new trustworthy social bonds (Flam \& King, 2005:31). Putnam's concept of social capital discounts and oversimplifies this phenomenon and its dynamics in the life of social networks.

In view of the above analysis, we argue that power consciousness be added as an essential variable to galvanize trust and reciprocity into action in social capital theory, where power is defined as 'the ability to influence and control social and [economic] activities' (Islam, 2008:1-2). It is anticipated that once trust and reciprocity are galvanised through power consciousness, the resulting action will be a 'conversion' to 'critical trust' and 'critical reciprocity' which will result in active participation amongst citizens.

Bilgic (2013:8) looks at different dimensions of power (power-to; power-over and power-with), where 'power-with is defined as the kind of power that stems or emerges from collective action'. Critical to add is a dimension of 'power within' which is the kind of power that resides 'within' each person. This is the kind of power that enables 'agency'; thereby creating 'power-with' in a collective. Agency, in this context, is defined as 'actions of individuals or groups, and their capacities to influence events' (Thomas \& Allen, 2000:122).

In feminist theory, the idea of working with power is to 'reorder power and not eliminate it, to focus on the [communal] use of power and its infinite capacity for transformation and not to dismantle it' (Grosz, 2010:19).

This is the role that is intended with the interweaving of power pedagogy in social capital theory, to reorganise the balance, flow and share of power in social networks such that it facilitates 'critical trust' and critical reciprocity'. Our idea of critical trust is that it is the ability to believe that other people have our best interest at heart and they will not deliberately hurt us based on a shared sense of class and power consciousness that is embedded in respectful, open, and honesty negotiated settlement between individuals and/or groups in society.

Similarly, we view critical reciprocity as the ability to return favours based on a sense of shared power and class consciousness that is embedded in respectful, open, and honestly negotiated settlement between individuals and/or groups in society. The word critical in this context means 'containing careful or analytical evaluations [of the status quo]' (thesaurus.com/browse/Critical, retrieved: 10 February, 2013).

We have decided to name phenomenon described above as a 'Critical Reciprocity-Critical Trust' [CRCT] model. The fundamental requirement for the CRCT model is a space for the reorganisation of power through constructive dialogue to enable the emergence of collective consciousness whose result is transformative and communal use of power based on a negotiated settlement in a collective. This is what Grosz (2010:19) asserts to be the purpose of feminist theory. This space for dialogue is called the 'Critical Centre', a place of convergence, dialogue and conversion of diverse power sites into critical reciprocity and critical trust in a network. However, the 'Critical Centre' can only happen once there is acknowledgement and or willingness to engage with different ideas of the desired change in society from different individuals and groups within a collective.

This requires that individuals and groups declare their desired 'interests' about the ideas of a change they seek to see in the world. Interest in this context is defined as 'a power aspect of something that attracts attention' (Encarta Dictionary, 2013). The declaration of interest happens at a place called the 'ideological centre', where ideas are conceptualised in the CRTC model. The end result is the formation of what we call a 'Critical Action Base' [CAB], which takes the form of social networks, social groups, social movements an even social capital as defined by Putnam 
(2000:19). This is the place where active participation becomes inevitable.

However, it must be noted that the CRTC model may not fit the conceptualisation of social capital theory given concerns that the concept of social capital is 'a misleading metaphor' because it is not 'capital' in the true sense of the word; it only describes relationships between people, which are not capital (Haynes, 2009:4). In that case, the CRCT model must serve as the foundation of an alternative 'social organising theory' in itself.

In summary the CRCT model proposes three fundamental phenomena to facilitate active participation in society, namely:

i. An Ideological Centre [IC], which is a place where ideas and concepts about the desired world are produced.

ii. A Critical Centre for Constructive Dialogue [CCCD], which is a space for the reorganisation of power through constructive dialogue to enable the emergence of collective consciousness whose result is transformative and communal use of power based on a negotiated settlement in a collective.

iii. A Critical Action Base [CAB], which is an organised web of social formations of different kinds galvanised for a collective purpose towards the attainment of desired change in the world.

These fundamentals are glaringly absent in the conceptualisation of social capital theory. A compelling argument is that they be inserted as power pedagogy to extend the development of social capital theory or they serve as a foundation for the development of a social organising theory as an alternative. See FIGURE 1 for a summary of the CRCT model.

It is of paramount importance to state that Putnam (2000:19) was correct in asserting that trustworthiness and reciprocity have a pivotal place in the life of social networks in society. This remains a valuable contribution to social theory despite the gaps articulated above, particular when thinking about bonding social capital, defined as 'attachment to, commitment to, involvement and belief in individuals that a person is connected to' (Hirschi 1969:251-256). In addition, most scholars have found bonding social capital to be a useful theoretical tool to analyse and explain sustainable bonds within different homogeneous groups in society. (Brisson \& Usher, 2005:644-653; Edward, Franklin \& Holland, 2003:1-35; Dhakal \& Lilith, 2011:1-11).

The gaps identified in this research are more applicable to linking social capital which is comprised of 'formal networks connecting members of voluntary organizations and formal networks of activists in political parties' [e.g. partnerships between government and civil society organisations] (Sabatini, 2006:23); and bridging social capital, which is the bringing together of groups that are different from one another [e.g. race, class, gender, sexuality networks] (Woolcock \& Sweetser, 2002:26).

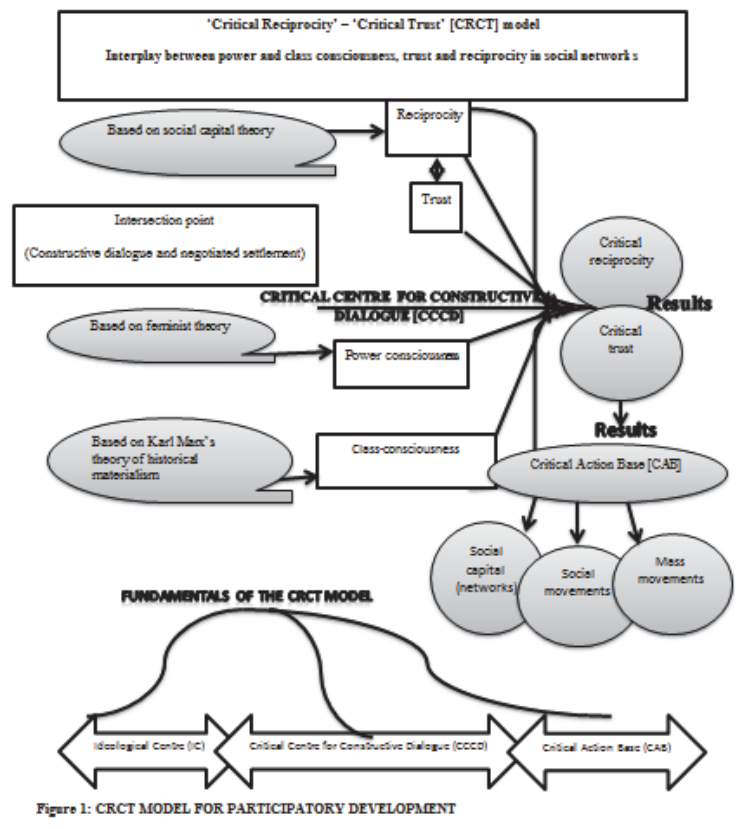




\section{Research Question}

In the context of the research problem identified above, the main purpose of this research was to provide an answer to the following questions:

$\checkmark$ RQ1: What is the level of participation amongst African Traditional Health Practitioners in the regulation of African Traditional Medicines in South Africa?

$\checkmark$ RQ2: Do trust, reciprocity and power play any particular role in determining the levels of public participation?

\section{Aim of the Study}

The aim of this research was to measure the level of participation amongst African Traditional Health Practitioners at Thembisile Hani local municipality in Mpumalanga and examine whether trust, reciprocity and power affect public participation in the regulation of African Traditional Medicines in South Africa.

\section{Hypotheses}

Creswell (2003:108) defines hypotheses as predictions the researcher holds about the relationship between variables. Creswell (2003:109) further states that there are two forms, namely, the null hypothesis, which 'predicts that no relationship exists between variables' and an alternative hypothesis 'which predicts a causal relationship between variables' (2003:110). The following are the hypotheses that were tested in the study:

H01 (Null hypothesis 1): There is no correlation between trust and public participation in the context of the regulation of African traditional medicines in South Africa. The equation here is that if $X$ (trust) exists; no observable change in $Y$ (public participation) will be noted.

H11 (Alternative hypothesis 1): The level of participation (dependent variable) amongst ATHPs is very low due to high levels of trust (independent variable) in the democratic government to protect their best interests as African traditional health practitioners. The equation here is that if $X$ (trust) exists; an observable change in $Y$ (public participation) will be noted.

H02 (Null hypothesis 3): There is no correlation between class and public participation in the context of the regulation of African traditional medicines in South Africa. The equation here is that if $X$ (class) exists, no observable change in $Y$ (public participation) occurs.

H12 (Alternative hypothesis 3): ATHPs are willing and eager to respond to and engage in government's invitations to public processes in the regulation of ATMs but they do not have the financial resources and sufficient education required to attend and engage in public meetings and thereby undermine their own ability to engage at government level. The equation here is that if $\mathrm{X}$ (class) exists, an observable change in $\mathrm{Y}$ (public participation) occurs.

H03 (Null hypothesis 4) = there is no correlation between power and public participation in the context of the regulation of African traditional medicines in South Africa. The equation here is that if $X$ (power) exists, no observable change in $Y$ (public participation) occurs.

$\mathrm{H} 13$ (Alternative hypothesis 4): ATHPs do not believe that they have the power to influence decision making in the regulation of ATMs because government will do what they want regardless of what people think or say. The equation here is that if $X$ (power) exists, an observable change in $Y$ (public participation) occurs.

\section{Methodology}

There are two major traditions of research methodology in the field of social sciences, i.e. quantitative and qualitative methodologies (Firestone, 1987). Considering the relevance with the topic, the study employed a quantitative methodology. This has been done by carrying out a questionnaire survey. The following section gives an indication of research tools that were used to collect data.

\subsection{Self-administered questionnaire}

Babbie and Mouton $(2001,233)$ indicate that a 'self-administered questionnaire is a written compilation of questions by a researcher administered to respondents for self-completion'. According to Gambarino and Holland, (2009) a questionnaire survey generate quantifiable data and can be analysed statistically, with the purpose of aggregating, measuring, modelling and predicting behaviour and relations. A self-administered questionnaire was used as a data 
collection tool and structured in themes, followed by a set of questions under each theme to guide respondents. There were four themes identified on the questionnaire, namely: (1) biographical data, (2) public participation, (3) the role of trust and reciprocity in public participation, and (4) the role of class status and power in public participation.

\subsection{Sampling}

The study used non-probability purposive sampling, which permits the selection of a sample from the population based on the 'researcher's judgment and purpose of the study' (Babbie \& Mouton, 2001:166). This is to recognise the fact that the researcher is known to the study population and this, as a result, facilitates making judgements on sample selection. As a result, the use of a structured questionnaire was a deliberate attempt to minimise subjectivity in the research process.

\subsection{Data Analysis Methods}

The survey data was analysed with STATA, 'a full-featured statistical programme for Windows, Macintosh and Unix computers' (Hamilton, 2009:1) designed to analyse quantitative data statistically. Yang (2010:7) indicates that 'statistics is a tool for discovering meaningful information from a large amount of numeric data. It is most useful for obtaining concise and precise information about a large number of cases'. STATA assists in determining, from the data set, whether a positive or negative correlation between dependent and independent variables exists.

\section{Limitations of the Study}

The limitation of the study is that it relies on quantitative methods, which do not always provide detailed narratives of the responses given, thereby missing important nuances and motives for responses. The rationale for selecting quantitative methods was informed by budgetary and time constraints required to complete the study. Quantitative methods proved to be affordable and faster compared to qualitative methods. In addition, the findings of the study are based on a small sample, caution needs to be taken not to generalise its conclusions to the overall population of South Africa.

\section{Ethical Statement}

The practice of social research can be a very sensitive and complicated engagement for both the people who are being researched and for the person conducting research. Babbie and Mouton (2001:521) note that 'it often, though not always, represents an intrusion into people's lives'. Social research often involves divulging of people's personal experiences, which constitute the fundamental aspects of people's livelihoods and identities. Denzin \& Lincoln (2008:463) assert that it needs a model that 'aligns the ethics of research with a politics of the oppressed and fosters accountability, caring and empathy'.

As a result, general ethics guidelines were given due respect in the study to avoid causing any harm to parties involved. Research participants took part in the study voluntarily and without any coercion. The researcher sought the consent of the participants before disclosing or revealing any confidential information. Participants were therefore informed about the nature, duration and purpose of the study. They were also informed about their right to withdraw at any time from the study should the need arise. Informed consent was obtained as well as informed decisions. During the process of data collection and information gathering, all the parties involved were informed about the purpose of the study and anonymity and confidentiality were ensured. In addition, the University of the Western Cape in South Africa provided ethical clearance to conduct the study.

\section{Results}

\subsection{Demographic data}

Table 1 demonstrates that the study sample was comprised of 75 respondents from the villages of Thokoza, Thembalethu, Vezubuhle and Kwaggafontein. The majority were female at $67 \%$ and youth at $32 \%$. The level of unemployment was very high. It stood at $96 \%$, and the few of those who were employed earned just above the minimum wage of between R3, 000 and R5, 000 a month. The level of education was very low since about $60 \%$ of respondents had no formal education and only $4 \%$ had obtained post-Grade 12 education. 


\subsection{Public participation in the regulation of African traditional medicines}

The level of participation was measured through two indicators, namely, involvement and decision-making. The results show that about $16 \%$ of respondents are actively involved and about $19 \%$ have direct influence in decision making. However, a high rate of $67 \%$ are not active, of which $44 \%$ were engaged with the process at a very low level and $23 \%$ did not know anything about the regulation of African traditional medicines in the country. Table 2 provides a summary of participation data.

Table 1: Demographic data

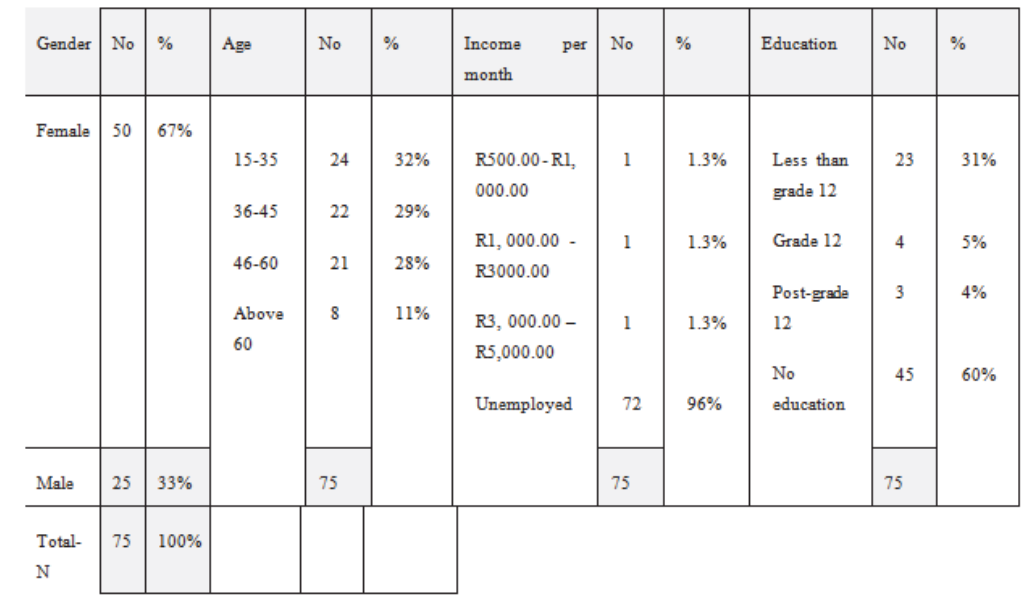

Table 2: Public participation data

\begin{tabular}{|c|c|c|c|c|}
\hline \multicolumn{3}{|c|}{ Dependant variable } & \multicolumn{2}{|r|}{ Public participation } \\
\hline Variable indicator & High & Moderate & Low & Don't know about the regulation process \\
\hline Involvement & $16 \%$ & $17 \%$ & $44 \%$ & $23 \%$ \\
\hline Decision making & $19 \%$ & $15 \%$ & $41 \%$ & $25 \%$ \\
\hline Averaged @ & $17.5 \%$ & $16 \%$ & $42.5 \%$ & $24 \%$ \\
\hline \multicolumn{2}{|c|}{ Independent variables } & \multicolumn{3}{|r|}{ Trust, reciprocity and power } \\
\hline & \multicolumn{2}{|c|}{ High } & Low & Not sure \\
\hline Trust & \multicolumn{2}{|c|}{$91 \%$} & $2 \%$ & $7 \%$ \\
\hline \multirow[t]{2}{*}{ Reciprocity } & \multicolumn{2}{|c|}{$100 \%$} & $0 \%$ & $0 \%$ \\
\hline & High & Moderate & Low & Not sure \\
\hline Power & $57 \%$ & $7 \%$ & $36 \%$ & $0 \%$ \\
\hline
\end{tabular}

\subsection{Power consciousness}

The power variable was concerned with measuring the ability of respondents to influence and control social processes, in this instance, decisions regarding the regulation of traditional medicines. The results show that $36 \%$ of respondents have low belief in their ability to influence decisions in the regulation of traditional medicines. Some of the reasons given included the fact that government always does what they want to do regardless of what citizens think or say. On the other hand, about $57 \%$ believed that they have the power to influence decisions made by government in the regulation of traditional medicines in the country.

The $57 \%$ majority cited knowledge of their constitutional right to be involved about and in government legislative processes that have a direct impact on their lives. The indication was that they are aware of their power as citizens to influence public processes and that power lies in the constitutional provisions for public participation. 


\section{Data Analysis}

We conducted a classical linear regression analysis to determine the correlation between dependent and independent variables. The purpose was to determine how the levels of public participation (public involvement and public decision making) are influenced by trust in government, willingness by citizens to respond to and engage in government regulation processes, levels of income, education and the power. The interest in this case is the statistical significance of the influence of class, power, trust and reciprocity in public participation. This is represented by the $P>|t|$ value in the regression analysis. We then used the $R^{2}$ to find out how much of the variation in the trust, reciprocity and power variables explains the changes in the participation variable.

\subsection{Classical linear regression analysis}

In analysing collected data, a classical linear regression model used was:

$Y=a+b K+c X+d L+\mu$, where $a$ is the intercept of the model, $b, c$, and $d$ represent regression coefficients, and $\mu$ is the random error term. However, the focus of the study was on the public participation regression coefficient (c), whose value gives the effect of public participation. The next paragraph provides analysis.

\subsection{Power consciousness determines whether citizens are involved in public decisions.}

Table 3 shows that income and power have a statistical significance of $P>|t| 0.001$ and 0.004 respectively in public participation which means a strong positive correlation between involvement, income and power exists. A positive correlation tells us that there is an 'association' between dependent and independent variables, and that association is 'moving in the same direction' for both variables (Greene and d'Oliveira, 2001). This means a decrease in $X=$ decrease in $Y$ and increase in $X=$ increase in $Y$.

Power in the context of this study is defined as 'the ability to influence and control social and (economic) activities' (Islam, 2008:1-2).

Similarly, this means that when citizen's power (independent variable) decreases by one unit, the value of participation (dependent variable) will decrease by the coefficient of variable X (power), which is 3824048 in the regression model.

Table 3: Linear regression analysis: involvement, income, education and power

\begin{tabular}{|c|c|c|c|c|c|c|}
\hline Source & ss & dt & XS & & Nunber of obs & $=$ \\
\hline Mode1 & 15.8279028 & $3 \quad 5.27$ & 596759 & & $p z o b>F$ & $=0.0005$ \\
\hline Residual & 56.8387639 & 71.800 & 545971 & & R-squared & $=0.2178$ \\
\hline Total & 72.66666667 & $74 \quad .981$ & 981982 & & Root uss & $=.89473$ \\
\hline involvenent & Coef. & std. Err. & t & p $>|t|$ & 1954 Conf. & Interval] \\
\hline incone & .6310496 & .1795429 & 3.63 & 0.001 & .2930512 & 1.009048 \\
\hline education & -.1279019 & .0920543 & -1.39 & 0.169 & -.311453 & .0556492 \\
\hline power & .3824048 & .1285657 & 2.97 & 0.004 & .1260522 & .6387575 \\
\hline cons & -.7518399 & .8711398 & -0.86 & 0.391 & $-2,488843$ & .9851634 \\
\hline
\end{tabular}

Only $21 \%$ of the variation between the dependent and independent variables is explained by this model. There is a need for further interrogation on other factors that may be responsible for low levels of public participation amongst African traditional health practitioners. Nevertheless, based on the regression model above, one can conclude that power, as an independent variable, plays a significant role in determining the levels of participation. The results above revealed that $36 \%$ of respondents do not believe that they have the power to influence decisions in the regulation of traditional medicines. The motivation for this was stated as the fact that government will always do what they want to regardless of what citizens say or think. The regression model above suggests that if this percentage can increase, the levels of public involvement will also continue to drop amongst traditional health practitioners by 3824048 units. 


\subsection{Confirmed hypothesis}

Based on the results and analysis above, the following hypothesis was accepted:

H13 (Alternative hypothesis 4): ATHPs do not believe that they have the power to influence decision making in the regulation of ATMs because government will do what they want regardless of what people think or say. The equation here is that if $X$ (power) exists, an observable change in $Y$ (public participation) occurs.

The rationale for accepting the above hypotheses is strengthened by the statistical significance of $P>|t| 0.004$ in power.

The results on the role of trust and reciprocity in social capital (public participation) require further investigation since they did not demonstrate any significance statistically in this study. Further interrogation of the link between high levels of trust and willingness to engage with government and the low levels of participation on the other hand is also essential. Such an interrogation needs to make direct links to the critical role of power and class in trust and reciprocity and test what happens when citizen's trust and reciprocity is conscientised through power consciousness raising programs. This means that the investigation must be focused on testing why citizens trust so naturally without questioning things and why they are quite willing to support government even when government demonstrates very little interest in and commitment to engaging with them.

\section{Discussion}

\subsection{Politicisation of trust and reciprocity in public participation is an imperative}

The first link to identify is that trust and reciprocity do play a significant role in social capital (Putnam, 2000:19), in this particular instance, linking social capital (Sabatini 2006:23; Woolcock, 2001:23; Mayoux, 2001: 108). In this study however, it seems to have played a negative role in that people have decided to disengage from public processes on the basis of trust placed on the democratic government. The high level of trust in government demonstrated in this study subverts people's willingness and eagerness to engage with public processes actively. There is a need for government to play a more active role in ensuring that people inform public decisions and engage in public processes, albeit, they have high levels of trust in the democratic state to represent their interests.

In addition, our analysis is that citizens seem to not engage with aspects of power that is embedded in public governance, especially when it comes to public decision making. It is important to understand that 'trust' is essential for building and sustaining social capital in society, but because trust, once constructed, lives in people's hearts, it is therefore personal and because it has influence in social relations, it is also political (Kleinman, 2007:2). In our minds political (critical) trust must be able to question, challenge and actively engage those who are placed in public power and trusted to deliver.

This means investing in collective consciousness raising and shared analysis of power embedded in social relationships as a fundamental base for trust and reciprocity in democracy (Wright. 1980:1; Bourdieu, 1968:53; Ollman, 1968:573; Kleinman, 2007:2), not just on naturalised acts of kindness based on anticipated rewards from cosmic forces, as suggested by Neusner and Chilton (2008:732). This must entail active politicisation of citizen's trust and reciprocity.

\subsection{Invoking citizen power consciousness for public participation}

It is critical to return to Bilgic (2013:8) to look at different dimensions of power (power-to; power-over and power-with), where 'power-with is defined as the kind of power that stems or emerges from collective action'. Critical to add is a dimension of 'power within' which is the kind of power that resides 'within' each person. This is the kind of power that enables 'agency'; thereby creating 'power-with' in a collective.

In this study, $57 \%$ of ATHPs indicated that they have the power as citizens to influence public decision making on pertinent issues that affect their lives, which they stated emerges from their guaranteed constitutional right to be consulted and engaged in public decision making. The constitution of South Africa provides in sections 72 (1) (a) and 118 (1) (a) that the legislature must facilitate public involvement in their legislative processes (SA Presidency, 1997). This is a guaranteed human right for all South African citizens.

So, citizens know where their power lies with regards to constitutional guarantees to public participation. The missing link is to understand why is it that they are not utilizing their power effectively to get involved in the public regulation of traditional medicines in this instance. Alternatively, could it be that the citizen's choice to trust government is in itself an act of active participation on their part? On the contrary, how could that be the case when $100 \%$ of 
respondents in the study indicated willingness to actively participate in the public regulation of traditional medicines if they could be invited and supported to do so, which suggests that they are aware that they are currently not actively participating? On the other hand, could this be what Cornwall (2008:270) define as passive participation and tokenism? Penderis (2012:7) was correct in asserting that there is an 'explosion of depoliticised participatory development in favour of neoliberal development agendas' in South Africa.

The state of public participation is South Africa is calling for new theoretical approaches. There is a need to come with innovative ideas, strategies and theories that are relevant to the changing context of South African democracy. Our proposal is that an in-depth review and observation of public participation processes be done at national level. This study must be done using the proposed CRCT model. As indicated the CRCT model proposes three fundamental phenomena to facilitate active participation in society, namely:

i. An Ideological Centre [IC], which is a place where ideas and concepts about the desired world are produced.

ii. A Critical Centre for Constructive Dialogue [CCCD], which is a space for the reorganisation of power through constructive dialogue to enable the emergence of collective consciousness whose result is transformative and communal use of power based on a negotiated settlement in a collective.

iii. A Critical Action Base [CAB], which is an organised web of social formations of different kinds galvanised for a collective purpose towards the attainment of desired change in the world.

These fundamentals are glaringly absent in the conceptualisation of social capital theory. A compelling argument is that they be inserted as power pedagogy to extend the development of social capital theory or they serve as a foundation for the development of a 'social organising theory' as an alternative. Such a theory could also be tested in other developing democracies in Africa, Asia and Latin America. See FIGURE 1 for a summary of the CRCT model.

In view of the above, a further interrogation on the status of public and citizen power in the context of participation that exists in South Africa is essential. The aim of such an interrogation must be to seek ways to reorder power in such a way that democratic processes work in favour of citizens and ensure active participation of the majority of citizens in the country, particularly the poor, vulnerable and marginalised communities.

\section{Recommendations}

The following recommendations are made based on the findings of this study

i. Conduct a follow up research study that examines the 'social conversion' of trust and reciprocity in social capital theory into 'critical trust' and 'critical reciprocity' using the proposed CRTC model

ii. Conduct a scientific review of state and citizen power in South Africa's democratic governance in view of the country's neoliberal economic and political context to assess the nature and success of South Africa's democracy in relation to the promotion of democratic citizenship and participation. This study should use a power analysis framework.

\section{Conclusion}

The findings of the study suggest that the majority of ATHPs in Mpumalanga are unemployed and have no formal education. Whilst the level of trust in government and willingness to participate in government processes by ATHPs is high at $91 \%$ and $100 \%$ respectively, the reality is that unemployment (96\%) and illiteracy $(60 \%)$ play a significant role in determining whether people participate or not in public processes. The assumption is that class differences are bound to emerge between ATHPs who work and those who do not, those who have education qualifications and those who do not. Such class differences will inevitably determine a person's nature and level of engagement within public processes as demonstrated by the findings of this study.

It is recommended that the national department of health develops a policy framework on public participation that will respond to the situation and close the social class gap by setting up public participation units within the national department of health and the Interim Council of Traditional Health Practitioners, and that a budget is set aside for their effective functioning and direct support of citizens to participate in public decision making. Besides the social class gap, it is not clear why else are ATHPs not actively involved in the public regulation of traditional medicines. A paradox exists in that ATHPs indicate a high level of willingness to participate and have high levels of trust in the current democratic government and yet the majority (67\%) is not actively involved in the regulation process. Moreover, about $57 \%$ indicate awareness of their power as citizens which is guaranteed in the constitutional right to be consulted by the legislature in all public decision making processes. However, this power seems not to be utilized.

This raises questions about public and citizen power and its use in democratic South Africa. A myriad of questions 
emerge. Is South Africa a passive democracy, tokenism democracy or are citizens using their democratic power decisively? Alternatively, could it be that the neoliberal economic and political context that exists in South Africa stifles critical citizen power and participation? It is recommended that further scientific research be conducted to interrogate these questions further.

Finally, trust and reciprocity in their natural state are clearly not adequate according to our findings. Our emerging hypothesis is that 'conversion' for trust and reciprocity is required in order to effect active participation. Such a conversion will only occur when 'trust and reciprocity' are placed next to 'power consciousness' to strengthen critical analysis for social capital to exist and be sustained. The interplay between trust, reciprocity and power creates space for questioning and analysis of socio-economic and political dynamics in public decision-making. A follow-up study is necessary to test this hypothesis. It is recommended that such a study uses the proposed Critical Reciprocity Critical Trust [CRCT] model to test its theoretical base.

\section{References}

Adloff, N. \& Mau, S. (2006). Giving social ties, reciprocity in modern society. European Journal of Sociology, pp. 47(1): 93-123.

Anheier, H .K. \& Kendall, J. (2000). Trust and voluntary organisations: Three theoretical approaches. Civil Society Working Paper 5. London, UK: Centre for Civil Society.

Arnstein, S. R. (1969). A ladder of citizen participation. Journal of the American Institute of Planner, pp. 35(4):216-224.

Babbie, E. \& Mouton, J. (2001). The practice of social science research. Cape Town, RSA: Oxford University Press.

Becker, G. S. (1996). Accounting for tastes. Cambridge, MA: Harvard University Press.

Bilgic, A. (2013). Trust and power of social movements: The case of feminist solidarity in Tahrir. Ankara, Turkey: Bilkent University Press.

Block, N. (1975). Introduction: What is functionalism. Journal of Philosophy, pp. 20:171-183.

Bourdieu, P. (1968). The forms of capital. In J. E. Richardson (Ed.). Handbook of theory of research for the sociology of education. West Point, CN: Greenwood Press.

Brisson, D. S. \& Usher, C. L. (2005). Bonding social capital in low-income neighborhoods. Family Relation, pp. 54: 644-653. Oxford, UK: Blackwell.

Buccus, I. Hempson, D. Hicks, J. \& Piper, L. (2007). Public Participation and Local Governance.. Center for Public Participation, Human Science Research Council \& the University of Kwa-Zulu Natal. South Africa

Burns, D. R., Hambleton, P. \& Hoggett, P. (1994). The politics of decentralisation. London, UK: Macmillan.

Chambers, R. (1994a). Paradigm shifts and the practice of participatory research and development. Working Paper 2. Institute of Development Studies

Chambers, R. (1994b). Participatory rural appraisal (PRA): Analysis of experience. World Developmen, pp. 22(9): 1253-1268.

Cliff, T. (1973). Lenin and the Revolutionary Party. Reprint from the International Socialist Tradition. Originally printed in International Socialism, pp. 58:34-38.

Coleman, J. S. (1988). 'Social Capital in the Creation of Human Capital.' American Journal of Sociology, pp. 94:95-120

Coleman, J.S. (1990). Social capital. London.UK. Cambridge University Press.

Collins, A. \& Ison, R. (2006). Dare we jump off Arnstein's ladder of participation? Social learning as a new policy paradigm. Milton Keynes, UK: The Open University.

Creswell, J. W. (2003). Research design: Qualitative, quantitative, and mixed methods approaches. (2nd ed.). London, UK: Sage.

Cornwall, A. (2008). Unpacking 'Participation': models, meanings and practices. Community Development Journal, pp. 43(3):269-283. Oxford University Press.

Della Porta, D. (2012). Critical trust: Social movements and democracy in times of crisis. Anno II, Numero, pp. 4:33-44.

Denzin, N. K. \& Lincoln, Y. S. (2008). Collecting and interpreting qualitative materials. London, UK: Sage.

Encarta dictionary. (2013). English. United Kingdom [online]

Flam, H. \& King, D. (2005). Emotions and social movements. London, UK: Routledge.

Franklin, J. (2007). Social capital: Between harmony and dissonance. London, UK: South Bank University Press.

Firestone, W. A. (1987). Meaning in Method: The Rhetoric of Quantitative and Qualitative Research. Educational Researcher, 16(7), 1621.

Gambarino, S., \& Holland, J. (2009). Quantitative and Qualitative Methods in Impact Evaluation and Measuring Results. Governance and Social Development Resource Centre. .

Gouldner, A. W. (1959). Reciprocity and autonomy in functional theory. In Gross L Z. (Ed.) Symposium on sociological theory: Evanston,Ill: Row, Peterson. pp. 241-270. L.Gross, editor Symposium on Sociological Theory, Evanston,Ill.: Row, Peterson, 1959, pp. 241-270.

Grosz, E (2003) 'Histories of the Present and the Future: Feminism, Power, Bodies' in J. J. Cohen, \& G. Weiss (Eds) (2003), Thinking the Limits of the Body. Albany: SUNY Press HM636 T44.

Gundogan, E. (2008). Conceptions of hegemony in Antonio Gramsci's 'Southern Question and the Prison Notebooks'. New Proposals: Journal of Marxism and Interdisciplinary Inquiry, pp. 2(1): 45-60

Hamilton, L. C. (2009). Statistics with STATA, Updated for Version 10. Toronto, Canada: Books/Cole. 
Hanifan, L. J. (1916). The Rural School Community Centre. Annals of the American Academy of Political and Social Sciences, pp. $67: 130-138$

Haynes, P. (2009). Before going any further with social capital: Eight key criticisms to address. Working Paper No 2009/02. Ingenio. Universidad Politecnica de Valencia.

Hirschi, T. (1969). A control theory of delinquency. Berkeley, CA: University of California Press.

IAP, (2013). Global Network for Science Academics Good public participation results in better decisions. Retrieved from http://www.iap2.org/

Islam, S. (2008). Power in social organization: A sociological review. Bangladesh e-Journal of Sociology, pp. 5(1): 1-12.

Kleinman, S. (2007). Feminist Fieldwork Analysis: The personal is political. Little Blue Books, pp. 8: 1-28. [Online]

Lin, N. (1999). Building a Network Theory of Social Capital. Connections, pp. 22 (1):28-51

Loury G. C. (1977) A dynamic theory of racial income differences. In P.A. Wallace, A. Le Mund (Eds). Women, minorities, and employment discrimination. Washington DC: Lexington Books.

Mollering, G. (2001). The nature of trust: From Georg Simmel to a theory of expectation, interpretation and suspension. Sociology, pp. 35(2): 403-420

Molm, L. D., Collett, J. L. \& Schaefer, D. R. (2007). Building solidarity through generalised exchange: A theory of reciprocity, American Journal of Sociology, pp. 113(1):205-242.

Neusner, J \& Chilton, B. (2008). The golden rule: The ethics of reciprocity in world religions. Anglican Theological Review, pp. xii: 730 731

Nkangala District Municipality, (2010). NDM Integrated Development Plan 2011-2016. Nkangala. Mpumalanga.

Nyalunga, D. (2006). An enabling environment for public participation in local government. International NGO Journal, pp. 1(1):1-6 [online].

Ollman, B. (1968). Marx's use of 'class'. The American Journal of Sociology, pp. 73(5): 573-580. Chicago University Press.

Penderis, S. P. (2012). Theorising participation: From tyranny to emancipation. Journal of African and Asian Local Government Studies, pp. 1(3):1-28.

Portes, A. (2007). Social capital: Its origins and applications in modern sociology. Annual Review of Sociology, pp. 24(1):1-24.

Public Service Commission (PSC). (2008). Report on the Assessment of Public Participation Practices in the Public Sector. Pretoria, RSA: The Public Service Commission.

Putnam, R. (2000). Bowling alone: The collapse and revival of American community. New York, NY: Simon \& Schuster.

SA Presidency. (1997). Constitution of the Republic of South Africa, Act 108 of 1996. Government Gazette, No 38. Cape Town, RSA: Government Press.

Sabatini, F. (2006). The empirics of social capital and economic development: A critical perspective. FEEM Working Paper No. 15: Euricse.

Sachs, J. (2006). Doctors for Life vs. the Speaker of the National Assembly. Media summary. Constitutional Court. Republic of South Africa

SALGA, (2012). Local government handbook survey. Pretoria. RSA: South African Local Government Association.

Scott, R. (2009). An analysis of public participation in the South African legislative sector. MPA Thesis (School of Public Management and Planning). Stellenbosch, RSA: University of Stellenbosch Press.

Siphuma, Z. R. (2009). An assessment of the role of public participation in IDP: The Thulamela Municipality. University of Stellenbosch. South Africa

Stahl, C. (2009). Trust as fetish: A critical theory perspective on research on trust in e-commerce. Leicester, UK: De Montfort University (DMU).

Tadesse, E. Ameck, G. Christensen, C. Masiko, P. Mathakola, M. Shilaho W. \& Smith, R. (2006). The people shall govern: A research report on public participation in policy processes. Johannesburg, RSA: South African Centre for the Study of Reconciliation \& Action for Conflict Transformation.

Thembisile Hani Local Municipality, (2010). Final IDP document 2011-2016. Mpumalanga. Available at http://cgta.mpg.gov.za/IDP/Nkangala2010-11/ThembisilePart-3.pdf.

Thomas, A. \& Allen, T. (2000). Agencies of development. Oxford, UK: Oxford University Press.

Woolcock, M. \& Sweetser, A. T. (2002). Bright Ideas: Social capital - The bonds that connect. Asian Development Bank Review, pp. $34(2): 26-27$

Wright, E. O. (1980). 'Social Class'. Encyclopedia of Social Theory. Thousand Oaks, NJ: Sage.

Yang, K. (2010). Making sense of statistical methods in social research. London, UK: Sage.

Yakubovich, V. (2002). Between exchange and reciprocity: The interplay of institutions and social networks in the Russian labor market. Phd dissertation, Stanford University, USA. 